\title{
ANALYSIS OF PARAMETERS WHICH AFFECT REGULARITY OF AIR FLOW IN PERFORATED PIPE ${ }^{1}$
}

\author{
Sławomir Kurpaska ${ }^{\mathrm{a}^{*}}$, Hubert Latała ${ }^{\mathrm{a}}$, Dariusz Baran ${ }^{\mathrm{b}}$ \\ ${ }^{a}$ Institute of Agricultural Engineering and Informatics \\ ${ }^{\mathrm{b}}$ Institute of Machinery Management, Ergonomics and Production Processes \\ University of Agriculture in Krakow
}

*Corresponding author: rtkurpas@cyf-kr.edu.pl

\begin{tabular}{l}
\hline ARTICLE INFO \\
\hline Article history: \\
Received: October 2016 \\
Received in the revised form: \\
November 2016 \\
Accepted: December 2016 \\
\hline Key words: \\
perforated pipe, air suction \\
local pressure losses \\
\\
\hline
\end{tabular}

ABSTRACT
The paper presents the results of analysis which enable determination
of the value of the pressure losses coefficients which occurred during
air suction and flow through a perforated pipe. Knowledge on them is
indispensable for determination of regularity of air suction along the
considered pipe. Exiting the basic energy equation, firstly a local
coefficient of pressure losses was determined and then the form of the
relation for its determination in the function of independent variables
was found out. In the second stage, the value of pressure losses caused
by mutual crossing of two streams (axial stream and stream sucked by
the side surface of a pipe) was determined. Also, for this coefficient,
the form of the correlation equation including power relation between
the independent variables was emphasised. The calculated values of
the discussed coefficients from determined forms of correlation
equations are satisfactorily compliant with the calculated values from
the experiments which were carried out.

\section{The list of symbols:}

$d \quad$ - diameter of pipe, $(\mathrm{m})$

$l \quad-$ length of pipe, $(\mathrm{m})$

$n_{i} \quad$ - number of openings in the pipe walls, (-)

$F_{i} \quad$ - field of cross section of opening in pipe $\left(\mathrm{m}^{2}\right)$

$F_{i} \quad$ - field of cross section in pipe $\left(\mathrm{m}^{2}\right)$

$V \quad-$ axial speed of flowing air $\left(\mathrm{m}^{-1} \mathrm{~s}^{-1}\right)$

$V \quad$ - speed of flowing air $\left(\mathrm{m}^{-1}\right)$

$\Delta P_{s t} \quad$ - static underpressure in perforated pipe, $(\mathrm{Pa})$

$\varphi \quad-$ coefficient of the pipe wall perforation, (-)

$\rho \quad$ - density of sucked air $\left(\mathrm{kgm}^{-3}\right)$

1 Research results were financed from the subsidy on science granted by the Ministry of Science and Higher Education 
Analysis of parameters...

$$
\begin{array}{ll}
\lambda & - \text { linear losses coefficient, }(-) \\
\xi_{W E} & - \text { coefficient of air inlet losses, (-) } \\
\xi_{P R Z} & - \text { coefficient of air cross flow losses, (-) }
\end{array}
$$

\section{Introduction}

Many facilities impose the requirement of equal air transport along the installed perforated pipe. It also concerns fresh air supply as well as its removal from premises. Practical use of this system in roofed facilities (installation of an additional pipe under cultivation gutters, in mushroom growing rooms and in other facilities where obtaining uniform environmental factors is required. Structural details of perforated pipes for pressing air to facilities, applied hydraulic calculations may be found in specialist studies (e.g. Pelech, 2009). Except for the air pressing installation, the concept of ensuring equal air flow on the entire length of the pipe plays a significant role in the systems which remove air from premises. Such systems may be used in premises where a uniform concentration or temperature is required (ventilation and removing odours from premises, ensuring uniform air stream for heat storing in energy batteries). The concept of cooling the inside of the facility was the subject of analysis carried out inter alia by Mongkona et al., (2014). These authors considered the air suction system from the inside of premises and the theoretical description restricted to a single-dimensional concept, where they analysed the sucked air flow speed as a function of resistance and pressure distribution in the pipe. Kurpaska and Latała (2010) investigated the issue more thoroughly because they analysed the heat storage system in the soil battery, where hot air was supplied with the system of perforated pipes. A regular division of air stream at the pipe length was assumed. Karki and Patankar (2006) used basic equations (of speed, energy storage) for air flow through a perforated pipe wall based on which they developed a simulation model and the obtained experimental results verified with calculated values. Air flow in the pipe inside which a porous material was placed (pressure losses along with the thermal concepts) were analysed by Ko and Anand (2003). Issues related to air flow (heat penetration, pressure, friction, change of pressure) in the perforated pipe were the subject of analyses carried out by Dutta and Dutta (1998), Hwang (1995) and Liu and Chen (1998). Analysis was carried out for various geometrical configurations of the pipe and for various conditions of the surrounding. On the other hand, Greig et al., (2012) carried out a series of experiments analysing the air flow in the corrugated porous channel where hot air was sucked from the surroundings. Issues related to ventilation of a facility (a piggery) in a real facility and at a laboratory stand were analysed by Ni et al., (2016). Vorontsov and Wachowicz (2008) presented a mathematical model of the air flow process in ventilation chambers of a mushroom growing room. Equal air distribution in a mushroom growing room was obtained due to the use of optimization methods for calculation of surface areas of vents in the ventilation channel.

The presented review shows that the problem of air flow through the perforated pipe is very complex and many researches deal with it. According to the authors, the issue is additionally complicated because along with the change of the air flowing stream, also dynamic conditions related to the relation - the main stream - the stream of sucked air, change. These relations result from flow resistance, both linear and local (which occur on 
Analysis of parameters...

the border of main stream and air stream flowing through the perforated side of the pipe). Analysis of these issues is the main objective of the paper.

\section{Material and method}

Tests were carried out at the measuring stand, the scheme of which was presented in figure 1. A fan (W) through a perforated side surface of pipes sucks air from the surroundings. The marked measuring points serve for determination of the following parameters: air moisture and temperature, static underpressure and axial speed. During performance of experiments the following was measured: speed with the use of air motion measuring devices - Mini Air64; PT1000 sensors (temperature), air moisture sensors (HD2717T) and with sensors Huba - Control 964 (static underpressure). Measuring points were placed in points which were separated from each other with the distance $l$.

In the system which supplied the fan (WPT 700) an inverter was installed for regulation of the number of rotations of its rotator.

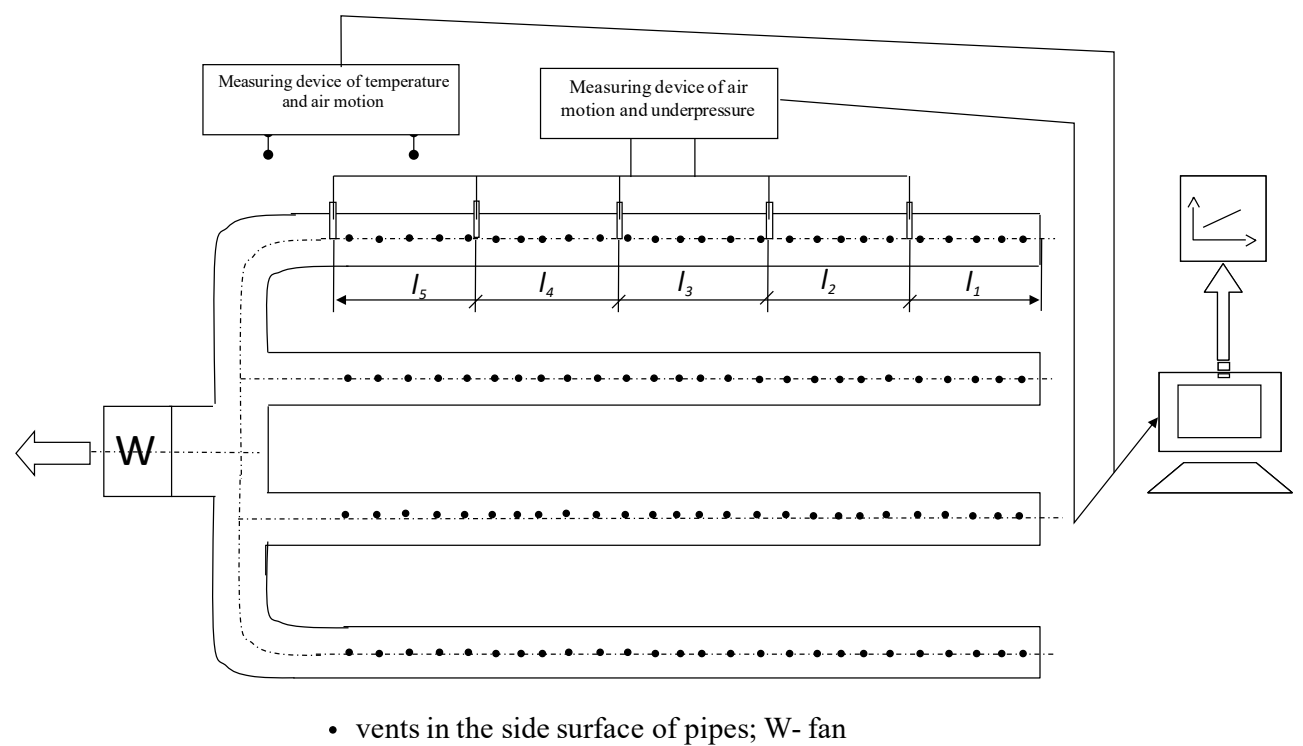

Figure 1. Schematic representation of test stand

Tests were carried out for the varied air stream (within 101-1170) $\mathrm{m}^{3} \cdot \mathrm{h}^{-1}$ ) and for the coefficient of the pipe wall perforation within 0.0003 to 0.0043 . This coefficient was calculated from the relation:

$$
\varphi=\frac{\sum_{i=1}^{n} F_{i} \cdot n_{i}}{F_{b}}
$$




\section{Theoretical analysis}

With regard to the energy maintenance principle which in the considered case may be described as follows: The sum of energy of pressure and the speed of air flowing through the pipe with any shape between any cross-sections, decreases by the amount of work consumed for fighting with the flow resistance at the length between them. Thus, Bernoulli's equation for any two cross sections $(i+1)$ and $(i)$ may be written down in the following form:

$$
\frac{\rho \cdot V_{i+1}^{2}}{2}+\Delta P_{i+1}+\left(P_{s t r}\right)_{i}=\frac{\rho \cdot V_{i}^{2}}{2}+\Delta P_{i}
$$

where:

$$
\begin{aligned}
& \Delta P_{i}, \Delta P_{i+1}-\text { static underpressure in the cross-section } i \text { and } i+1, \\
& \left(P_{s t r}\right)_{i} \quad \text { - pressure loss as a result of friction, } \\
& V_{i}, V_{i+1} \quad \text { - average air speed in cross sections of pipe. }
\end{aligned}
$$

In the detailed analysis, one should thus include pressure losses: linear and local. Local losses result from the air inlet through the perforated side surface and crossing of the stream of air flowing in the pipe with the sucked air stream. Figure $2 \mathrm{a}$ and $2 \mathrm{~B}$ presents graphically the considered cases.
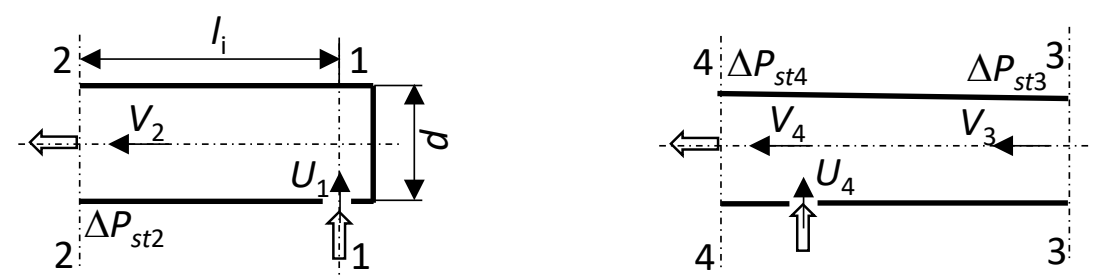

Figure 2. Analysed cases of air flow: (a)-stream of sucked air and crossed streams (b)

Thus, a pressure form of energy saving equation for case (a) takes the following form:

$$
\frac{\rho \cdot V_{2}^{2}}{2}+\Delta P_{s t_{2}}+\lambda \frac{l}{d} \frac{V_{2}^{2}}{2} \rho=\xi_{W E} \frac{U_{1}^{2}}{2} \rho
$$

on the other hand, in case of description of phenomena which occurred between the streams of flowing air and the stream of sucked air - case (b), Bernoulli's equation takes the following form:

$$
\Delta P_{s t 3}+\frac{\rho \cdot V_{3}^{2}}{2}=\Delta P_{s t 4}+\frac{\rho \cdot V_{4}^{2}}{2}+\lambda \frac{l}{d} \frac{V_{3}^{2}}{2} \rho+\left(\xi_{W E}+\xi_{P R Z}\right) \cdot \frac{U_{4}^{2}}{2} \rho
$$


Analysis of parameters...

In the assumed procedure, firstly the coefficient of air inlet losses $\left(\xi_{W E}\right)$ was calculated and then the function form was found: $\xi_{W E}=f(U, \varphi)$ and in the next step coefficient of air cross flow losses $\left(\xi_{P R Z}\right)$ was calculated.

In order to calculate the sucked air speed $(U)$ the equation of stream continuity was applied, where axial speed was used $(V)$. The basic psychometric relation (air density $\rho$ ) and equations for determination of linear losses coefficient $(\lambda)$ was used. For calculated coefficients multiple regression equations were found and the difference between the calculated values and measured ones were determined with the average elemental square error, known from the error estimation $(\sigma)$.

\section{Research results}

Almost 3000 measurements for independent variables were carried out: the rotational speed of the fan and the coefficient of the pipe side surface perforation. Figure 3 presents averaged values of the calculated air inflow coefficient $\left(\xi_{W E}\right)$ for variable perforation of the side surface $(\varphi)$ as a function of the flowing air stream.

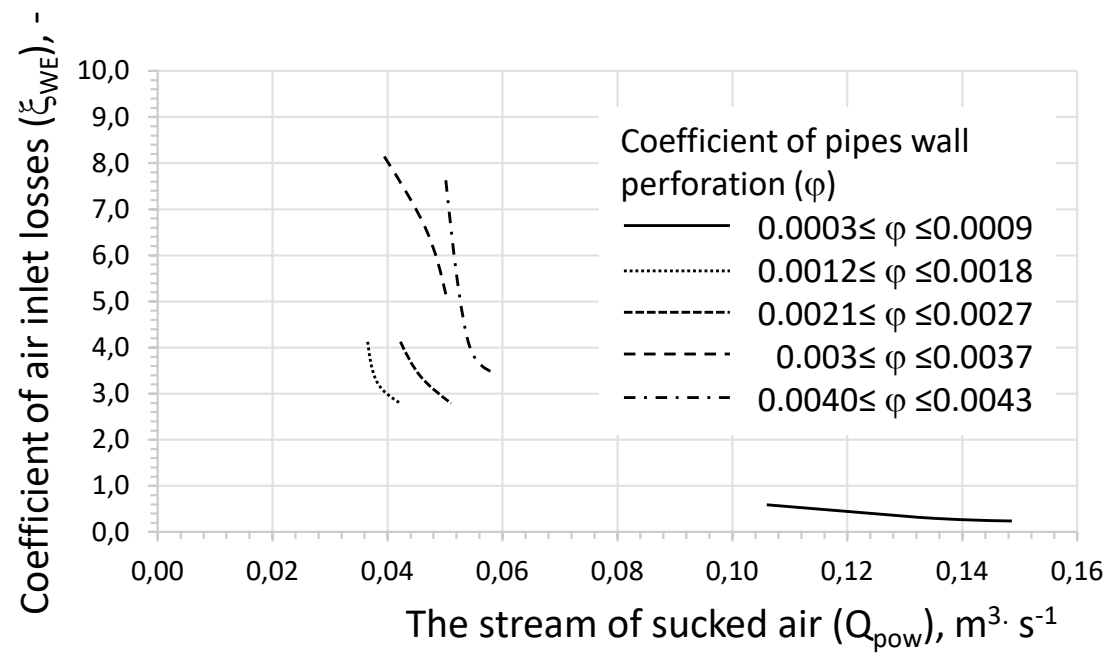

Figure 3. Impact of the flowing air stream on the averaged value of the coefficient of local losses of air inlet for the varied perforation of the pipe side surface

When analysing basic relations one may state that along with the increase of the flowing air stream, the value of local losses of inlet coefficient decreases. Such trend was observed for all analysed ranges of the perforation coefficient of the pipe side surface $(\varphi)$. The scope of changes of the coefficient value $\left(\xi_{\mathrm{WE}}\right)$, in the investigated scopes of independent variables is within 0.04 to 8.2 . 
Analysis of parameters...

According to the presented methodology, in the next stage variability of the inlet coefficient depending on the perforation coefficient and the air inlet speed was discovered. For the calculated values of the coefficient $\xi_{\mathrm{WE}}$, equation was found which includes the relation between this variable and independent variables (the form of a power model was selected based on the highest value of determination coefficient; this relation was determined with non-linear estimation with quasi-Newton method at the retained coefficient of convergence of 0.001 ) and takes the following form:

$$
\xi_{W E}=8.7 \cdot \varphi^{0.2}+15.7 \cdot U^{-1.96}-20.49 \cdot \varphi \cdot U ; \mathrm{R}^{2}=0.95
$$

within the scope of use: $0.0003 \leq \varphi \leq 0.0043 ; 0.7 \leq U \leq 154 \mathrm{~m} \cdot \mathrm{s}^{-1}$

Comparison between the measured and calculated values of the air inlet coefficient was presented graphically in figure 4 .

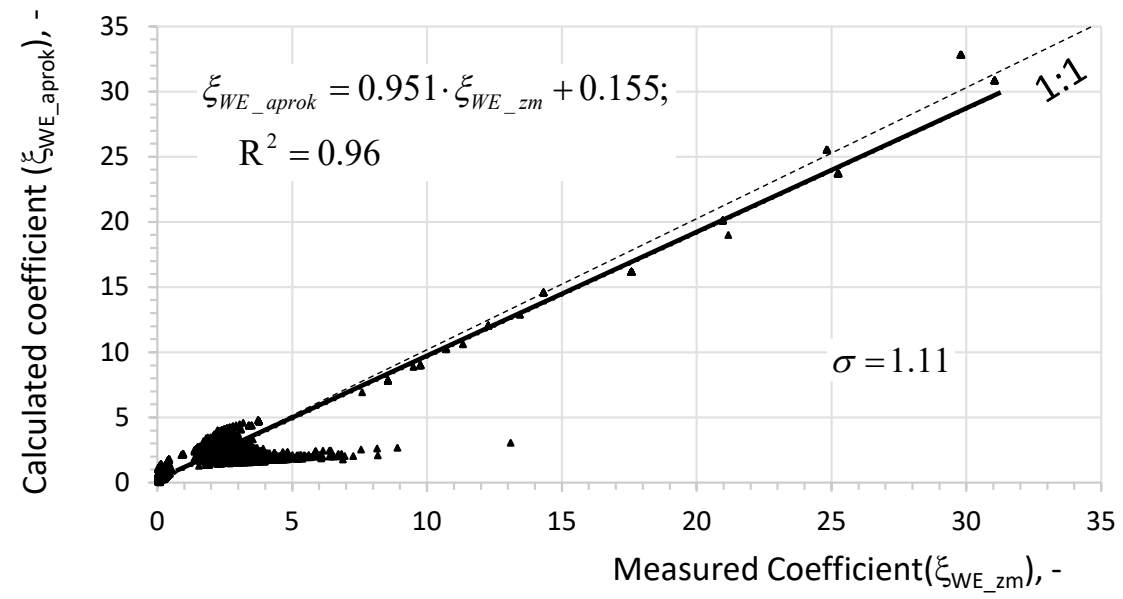

Figure 4. Comparison of courses of air inlet losses coefficient

The above equation was used for determination of the function relation of the air inlet coefficient, which will be used for calculation of the local losses coefficient related to the crossing of inlet streams and the sucked air (equation 4). The obtained results were presented graphically in fig. 5. In order to generalize the obtained results, the course of averaged values of the losses coefficient caused by crossing of air streams $\left(\xi_{\text {PRZ }}\right)$ were presented in the function of the coefficient of the flowing air stream speed in the pipe in relation to the speed of air sucked by vents made in the pipe wall. 


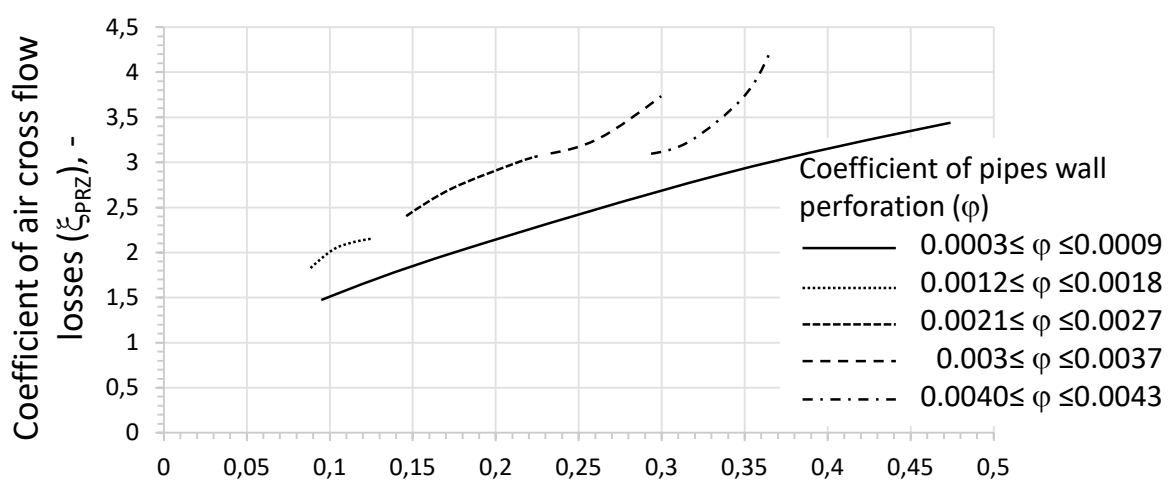

Relationship, $\mathrm{V} \cdot \mathrm{U}^{-1}$

Figure 5. Course of changes of the average coefficient of local losses resulting from crossing of air streams as a function of intensity of its flow for varied perforation of the pipe side

As we can see, independently from the value of perforation coefficient along with the increase of the relation of the air speed to the speed in vents of the side, its value increases. In the investigated conditions, average values of the pressure losses coefficient resulting from crossing of air streams $\left(\xi_{\mathrm{PRZ}}\right)$ are within 1.5 to 4.2.

For the measured factors of experiment, with the use of previous procedure, a form of equation for determination of the coefficient $\xi_{P R Z}$ was found in the following form:

$$
\xi_{P R Z}=1.39 \cdot V^{-0.41}+11.19 \cdot U^{-1.19} ; \mathrm{R}^{2}=0.89
$$

within the scope of use: $0.4 \leq V \leq 4.6 \mathrm{~ms}^{-1} ; 0.87 \leq U \leq 154 \mathrm{mss}^{-1}$

The presented results of comparison calculated from the found equation of values with values calculated from the experiments which were carried out were presented in figure 6 .

As we see, comparison of approximated results from the developed relation in comparison to the values measured, have comply satisfactorily with the results of measurements. Bigger differences between two sizes occur for higher values of the analysed coefficient. However, the statistical analysis carried out within the scope of confidence range for the slope and absolute term of found fractions which approximates the calculated coefficients (fig. 4 and 6) despite a high coefficient $R^{2}$ and a low value of error $\sigma$ indicates that one should try to find another function which approximates the analysed coefficients. 


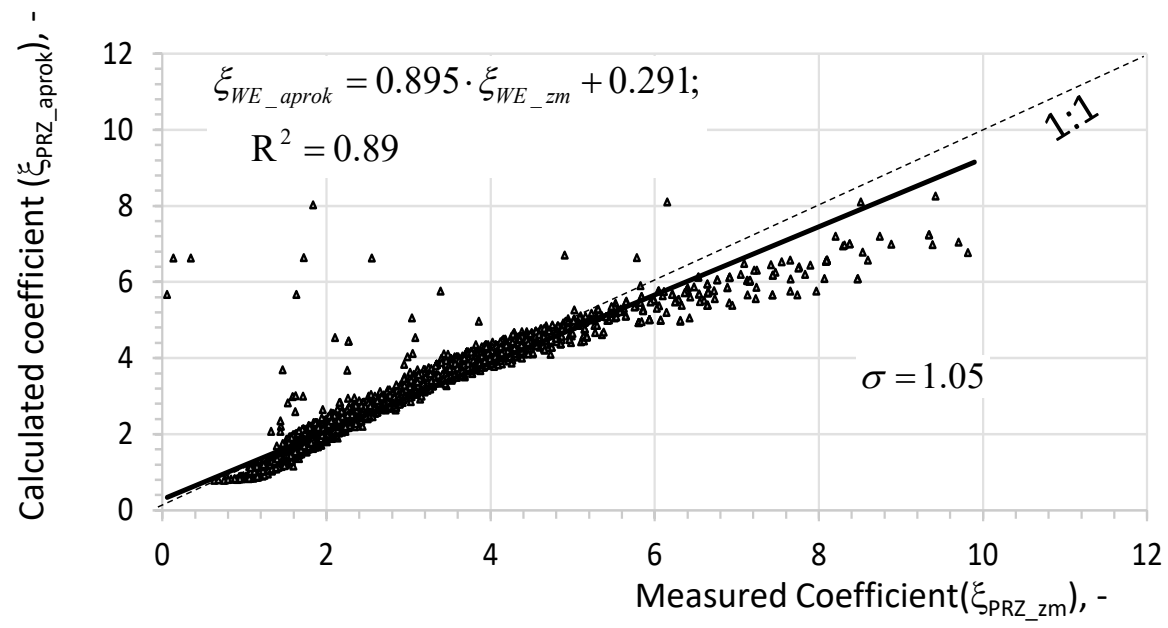

Figure 6. Comparisons between the calculated and measured values of the coefficient of pressure losses which occurred as a result of crossing air streams

To sum up, as a result of the experiments which were carried out, values of coefficients of local losses of pressure for the system of air suction through a perforated pipe side were found. Practical application of these results along with a description of experiments which were carried out which precondition the regularity of air suction along with the length of the pipe will be presented in the next paper.

\section{Conclusions}

1. The scope of changes of the air suction coefficient $\left(\xi_{\mathrm{WE}}\right)$, in the investigated scopes of independent variables is within 0.04 to 8.2 and losses coefficient at the crossing of air streams 1.5 to 4.2 .

2. The coefficient of local losses which describe the air intake through the perforated side is described by the relation:

$$
\xi_{W E}=8.7 \cdot \varphi^{0.2}+15.7 \cdot U^{-1.96}-20.49 \cdot \varphi \cdot U ; \mathrm{R}^{2}=0.95
$$

within the use: $0.0003 \leq \varphi \leq 0.0043 ; 0.7 \leq U \leq 154 \mathrm{~ms}^{-1}$

3. The local coefficient of losses which occurred as a result of crossing of flowing air streams in the perforated pipe as a function, is described by the following relation:

$$
\xi_{\text {PRZ }}=1.39 \cdot V^{-0.41}+11.19 \cdot U^{-1.19} ; \mathrm{R}^{2}=0.89
$$

within the use: $0.4 \leq V \leq 4.6 \mathrm{~m}^{-1} ; 0.87 \leq U \leq 154 \mathrm{~m}^{-1}$ 
Analysis of parameters...

\section{References}

Dutta, P., Dutta, S. (1998). Effect of baffle size, perforation, and orientation on internal heat transfer enhancement. International Journal of Heat and Mass Transfer, 41, 3005-3013.

Greig, D., Siddiqui, K,. Karava, P. (2012). An experimental investigation of the flow structure over a corrugated waveform in a transpired air collector. International Journal of Heat and Fluid Flow, $38,133-144$.

Hwang, J-J. (1995). Heat transfer in a rectangular channel with perforated turbulence promoters using holographic interferometry measurement. International Journal of Heat and Mass Transfer, 38(17), 3197- 3207

Ko, K-H., Anand, N.K. (2003). Use of porous baffles to enhance heat transfer in a rectangular channel. International Journal of Heat and Mass Transfer, 46, 4191-4199.

Karki, K.C., Patankar, S.V. (2006). Airflow distribution through perforated tiles in raised-floor data centers. Building and Environment. 41, 734-744.

Kurpaska, S., Latała, H. (2010). Energy analysis of heat surplus storage systems in plastic tunnels. Renewable Energy, 35(12), 2656-2665.

Ni, J-Q., Kaelin, D., Lopes, I., Liu, S., Diehl, C.A., Zong, C. (2016). Design and performance of a direct and continuous ventilation measurement system for variable-speed pit fans in a pig building. Bioosytems Engineering, 147, 151-161.

Liou, T-M., Chen, S-H. (1998). Turbulent heat and fluid flow in a passage disturbed by detached perforated ribs of different heights. Journal Heat and Mass Transfer, 41(12), 1795-1806.

Mongkon, S., Thepa, S., Namprakai, P., Pratinthong, N. (2014). Cooling performance assessment of horizontal earth tube system and effect on planting in tropical greenhouse. Energy Conversion and Management, 78, 225-236.

Pełech, A. (2009). Wentylacja i klimatyzacja - podstawy. Oficyna Wydawnicza Politechniki Wroctawskiej, ISBN 978-83-7493-445-9.

Vorontsov, L., Wachowicz, E. (2008). Modelowanie przepływu powietrza w kanałach wentylacyjnych pieczarkarni. Inżynieria Rolnicza, 10(108), 269-276.

\section{ANALIZA PARAMETRÓW WPLYWAJĄCYCH NA RÓWNOMIERNOŚĆ PRZEPLYWU POWIETRZA W PRZEWODZIE PERFOROWANYM}

Streszczenie. W pracy przedstawiono wyniki analizy umożliwiającej określenie wartości współczynników strat ciśnienia powstałych podczas zasysania i przepływu powietrza przez przewód perforowany. Ich znajomość jest niezbędna do określenia równomierności zasysania powietrza wzdłuż rozważanego przewodu. Wychodząc $\mathrm{z}$ podstawowego równania energii $\mathrm{w}$ pierwszej kolejności wyznaczono lokalny współczynnik strat ciśnienia, a następnie znaleziono postać zależności do jego wyliczenia $\mathrm{w}$ funkcji zmiennych niezależnych. W drugim etapie, wyznaczono wartość współczynnika strat ciśnienia spowodowanego wzajemnym krzyżowaniem się dwóch strumieni (strumień osiowy oraz zasysany przez pobocznicę przewodu). Również dla tego współczynnika pokreślono postać równania korelacyjnego ujmującego potęgowy związek między zmiennymi niezależnymi. Obliczone wartości rozważanych współczynników z wyznaczonych postaci równań korelacyjnych cechuje zadawalająca zgodność $\mathrm{z}$ wartościami obliczonymi z przeprowadzonych eksperymentów.

Słowa kluczowe: przewód perforowany, zasysanie powietrza, lokalne straty ciśnienia 